\title{
A correlation between students' morphological awareness and their accuracy in writing Recount text
}

\author{
Hafifah Azahra ${ }^{1}$, Rafista Deviyanti ${ }^{2}$ \\ FKIP Universitas Lampung, Jl. Prof. Dr. SoemantriBojonegoro No. 1, Rajabasa, Bandar \\ Lampung ${ }^{1,2,}$ \\ 1ªzzahrahafifah@gmail.com
}

\begin{abstract}
The purpose of this study is to find out whether there is a significant correlation between students' morphological awareness and their accuracy in writing recount text. This is quantitative research by using ex-post facto design. The population of the research was the students of the first grade of SMAN 1 Way Jepara. The researcher took five students from each ten classes as sample by using lottery, so total sample of students were 50. There were two instruments; the first test was morphological awareness test adapted from McBride-Chang et al. (2005) and Zakaria (2008) and the second test was writing a recount text test for measuring the students' accuracy in writing. The data were analyzed by using Pearson Product Moment Correlation in SPSS version 25. The result of the correlation analysis showed there was significant correlation between students' morphological awareness and their accuracy in writing recount text with coefficient correlation was higher than the critical value $(0.798>0.297)$ at significant level .01 . It means that the $\mathrm{H}_{1}$ is accepted and $\mathrm{H}_{0}$ is rejected.It can be concluded that morphological awareness influenced students' accuracy.
\end{abstract}

Keywords: Correlation, Morphological Awareness, Accuracy in Writing.

\section{INTRODUCTION}

Writing is an important part of communication that the students have to master in school. According to Byrne (1995) writing is transforming our thoughts to become language or written form. It is in line with the statement by Nunan (2003) writing is the physical act of committing words or idea, thinking about how to express them and organizing them into statements and paragraph that will be clear to the reader.

Therefore, many students think that writing is a complicated process to do since producing something is more difficult than receiving. According to Farooq et al. (2012), students often faced many difficulties in producing writing. The basis of all problems is the lack of grammar and the lack of vocabulary which make writing product become colorless, boring, and ineffective. When the students are assigned to make a writing task, they are still confused to choose appropriate word with correct structure to put their information that they want to share. The students need a lot of vocabularies when they are composing a paragraph, besides they have to write in grammatically correct in order to be comprehensible. 
The students are also expected to use language correctly and accurately when the teachers determine goals for students' language production. They must avoid the form of error that will occur, so that they can communicate the ideas effectively. According to the Oxford Advanced Learner's Dictionary (2005) the term accuracy refers to the state of being exact or correct, or the ability to do something skillfully without making mistakes. For common example, there are some students that understand the meaning of word but when they have to write in written form, they do wrong word formation by adding or removing -s, -es, -ed, -ing, -ly, -ness. In such a case, they do not just have to consider the skill of writing but also they should have morphological knowledge to manipulate the words.

According to (Carlisle, 1995; Larsen \&Nippold, 2007a; Nagy, Berninger, Abbott, Vaughan, \&Vermeulen, 2003) Morphological awareness refers to an individual's ability to consciously consider the structure of words in terms of the smallest meaningful units and to analyze and manipulate these units. In accordance with that, Zakaria (2018) states that morphological awareness is students' knowledge of how to form new word from root word. Certainly it will influence the result of their writing because, firstly, it develops vocabulary knowledge in line with their writing ability because morphological awareness is the ability to manipulate morpheme at word level. It is also easier for them to express the content they want to write by using the right vocabulary. Secondly, it will lead them to analyze the words by breaking them into its morphological components, which will help the students to guess its meaning. Thirdly, they can create correct structure of words and manipulate structure of words that they will use in their work. These factors can reduce the number of errors in writing, so that the students' writing accuracy will improve.

There are also some researchers who had conducted the research about morphological awareness. Mary Northey et al. (2015) said that children's morphological skill (specifically, morphologically manipulating words to condense syntax in a sentence combining task) was predictive of their essay writing qualities. The both of morphological skill and writing fluency are predictive of the content and organization score of the students' essays. Other studies by Silva et al. (2017) observed that children with better results in morphological awareness tests also presented better results in reading and writing, compared to those with inferior performance in morphological awareness or who did not undergo morphological intervention.

From the explanation above and those previous researches, the researcher is interested in doing the research about morphological awareness and accuracy in writing because the result of this study might help students' problem in writing recount text on the grounds that the researcher defines morphological awareness has a major effect on accuracy in writing. If the students have awareness in morphology, they are capable to use affixes to form new word, they easy derived complex word into new word, and they have lot understand of vocabulary, grammar, and spelling. 


\section{METHODS}

This was a quantitative research with ex-post facto design by using correlation study. Ex-post facto design was used when the researcher did not have control over the selection and manipulation of the independent variable (Hatch and Farhady, 1982). The population of the research was the students of the first grade of SMAN 1 Way Jepara. The researcher took five students from each ten classes choose as sample by using lottery with the total of students were 50 .

There were two instruments in this research; the first test was morphological awareness test from McBride-Chang et al. (2005) and Zakaria (2008). The researcher conducted it through online live test by using quizizz. The second test was writing a recount text test for measuring the students' accuracy in writing. The students had tosubmit their work through Whatsapp Personal Chat. Multiple-choice items were used to elicit the morphological awareness test. It consisted of 20 items; 10 questions for Morphological Structure Test and 10 questions for Morpheme Identification Test.Last, the data were analyzed by using Pearson Product Moment in SPSS 25.

\section{RESULTS AND DISCUSSION}

\section{Result}

After administering the test to the participants of the research, the researcher calculated the scores. The result of the test can be seen on this following table:

Table 1. Descriptive Statistic of Morphological Awareness

\begin{tabular}{|c|c|c|c|c|c|}
\hline \multicolumn{6}{|c|}{ Descriptive Statistics } \\
\hline & $\mathrm{N}$ & Minimum & Maximum & Mean & Std. Deviation \\
\hline $\begin{array}{l}\text { MA TOTAL } \\
\text { SCORE }\end{array}$ & 50 & 6 & 20 & 13.32 & 4.007 \\
\hline Valid N (listwise) & 50 & & & & \\
\hline
\end{tabular}

Table 2. The Quality of Students' Morphological Awareness

\begin{tabular}{|cccc|}
\hline CATEGORY & Score & Number of Students & PERCENTAGE \\
\hline High & $>17$ & 9 & $18 \%$ \\
\hline Average & $9-17$ & 34 & $68 \%$ \\
\hline Low & $<9$ & 7 & $14 \%$ \\
\hline Total & & $\mathbf{5 0}$ & \\
\hline
\end{tabular}


Table 1 shows that the highest score of students' morphological awareness is 20 and the lowest is 6 . The mean score is 13.2. Based on the mean score on the table, it can be seen that the students' morphological awareness is average. Also, table 2 shows that the numbers of students who have high morphological awareness are 9 (18\%), the students who have average morphological awareness are 34 (68\%), and 7 students with low morphological awareness (7\%).

Table 3. Descriptive Statistic of Accuracy in Writing

\begin{tabular}{|c|c|c|c|c|}
\hline \multicolumn{5}{|c|}{ Descriptive Statistics } \\
\hline & Minimum & Maximum & Mean & Std. Deviation \\
\hline Writing Accuracy & 50 & 98 & 82.38 & 8.985 \\
\hline Valid N (listwise) & 50 & & & \\
\hline
\end{tabular}

Table 4.The Quality of Students' Writing Accuracy

\begin{tabular}{|cccc|}
\hline CATEGORY & Score & Number of Students & Percentage \\
\hline HIGH & $>90$ & 14 & $28 \%$ \\
\hline AVERAGE & $72-90$ & 27 & $54 \%$ \\
\hline LOW & $<72$ & 9 & $18 \%$ \\
\hline
\end{tabular}

From table 3 above, it can be seen that the highest score of student's is 98 and the lowest score of the test is 66. The mean score is 82 . Table 4 shows the numbers of student who have high accuracy in writing are $14(28 \%)$. These students have good ability to avoid error in performance. They are great in using grammar, vocabulary, and spelling. Meanwhile, the students who have average accuracy in writing are 27 (54\%). It means that these students are good enough in using grammar, vocabulary, and spelling even though they still did some errors in writing. The students who have low accuracy in writing are $9(18 \%)$.

In order to find out whether there is a correlation between students' morphological awareness and their accuracy in writing recount text of the first grade students of SMAN 1 Way Jepara, the researcher used the coefficient correlation between both variables which were analyzed by using Pearson Product Moment correlation in SPSS 25. The following table shows the computation result of the two variables. 
Table 5. The Value of Pearson Product Moment Correlation Correlations

\begin{tabular}{|ll|r|r|}
\hline & & $\begin{array}{c}\text { Morphological. } \\
\text { Awareness }\end{array}$ & Writing.Accuracy \\
\hline Morphological.Awareness & Pearson Correlation & 1 & $.798^{* *}$ \\
\cline { 2 - 4 } & Sig. (2-tailed) & 50 & .000 \\
\cline { 2 - 4 } & $\mathrm{N}$ & $.798^{* *}$ & 50 \\
\hline Writing.Accuracy & Pearson Correlation & .000 & 1 \\
\cline { 2 - 4 } & Sig. (2-tailed) & 50 & 50 \\
\cline { 2 - 4 } & $\mathrm{N}$ & & \\
\hline
\end{tabular}

**. Correlation is significant at the 0.01 level (2-tailed).

From the table of calculation above, the researcher found that the coefficient correlation between students' morphological awareness and their accuracy in writing was 0.789 at the significant level at the 0.01 . It means that morphological awareness had strong correlation with students' accuracy in writing.

\section{Discussion}

Based on the result that the researcher has found, there was a significant correlation between students' morphological awareness and their accuracy in writing. Since the coefficient correlation was higher than the critical value $(0.798>0.297)$, it means that there was a significant correlation between students' morphological awareness and their accuracy in writing.

This finding supports the result of the research by Mary Northey et al. (2015) in their research of Contribution of Morphological Skill to Children's Essay Writing showed that morphological skills have important role in writing. It was said that children's morphological skill (specifically, morphologically manipulating words to condense syntax in a sentence combining task) was predictive of their essay writing qualities. In line with that Asaad\&Shabdin (2019) say that morphological awareness is a possible way of independent learning in which L2 postgraduate students would be able to use and strengthen their vocabulary knowledge and reduce the morphologically related errors made while writing.

Based on the whole result, there were students who had high and average morphological awareness also got high and average score in language accuracy. The students who had high accuracy in 
writing and high morphological awareness means that they had high ability to be error-free while using language to communicate. They also had capacity to handle whatever level of inter-language complexity s/he has currently attained. Their awareness of morphology could help them to write correct word structure when they write sentences then paragraph. The students with average accuracy and morphological awareness were actually good in using the language even though they did some errors in grammar, they could not manipulate the word and could not use the right vocabulary for their writing, and also they unconsciously made mistakes in spelling some words.

The students who had low score in accuracy also had low score in morphological awareness. Since both of variables were related, they influenced each other. The students with low accuracy in writing were low in elaborating the sentences into good grammar and form. They used wrong vocabularies in expressing their mind, and they were poor in spelling the words. It is clear that both variables were correlated significantly.

By emphasizing inflection morphological awareness, derivation morphological awareness, and building words from morphemes into complex word can help the students to improve their awareness of morphology. Awareness of inflectional morphemes should focus on associating the grammatical forms with their meanings. It involves mapping the concept of plural objects or the concept of an action for instance an action occurring in the present with the present progressive ing. Awareness of derivation morphemes focus on changing the semantic roles played by words within sentences. Derivational modifications can transform an adjective to a noun (electric, electrician), a verb to a noun (retaliate, retaliation), or a verb to an adjective (create, creative). Building words from morphemes can be illustrated at the compounding level when known words are combined to form new words.

According to the explanation above, it can be concluded that the study of morphology is important for student who wants to write a writing product. The researcher had found that students' morphological awareness had positive correlation with students' accuracy in writing. It means the higher students' morphological awareness, the higher their accuracy.

\section{CONCLUSIONS AND SUGGESTIONS}

There was a correlation between students' morphological awareness and their accuracy in writing recount text. Morphological awareness affected students' accuracy because they had no difficulties in making good words or sentences and avoid the errors if those students have awareness of morphology. It had an effect on their accuracy because the students had sufficient knowledge of root words, also they were able in using kind of morphemes such as inflection and derivation. Additionally, they could write well because they knew how to use appropriate vocabularies by compounding the morphemes. A correlation of students' morphological awareness and their accuracy in writing can be seen from the result of research which the coefficient correlation result of r-value (0.798) > r-table (0.297) at significant level .01. From that result, the null hypothesis (H0) 
is rejected and the research hypothesis (H1) is accepted. Therefore, it can be inferred that morphological awareness influenced students' language accuracy.

Based on the conclusion above, the researcher proposes a suggestion concerning the research finding as follow; first, in this research, the researcher only used recount text for students writing task in counting their accuracy. The researcher suggests to the teacher to give the students tasks such as identifying and analyzing the word for recognizable morphemes and think the possible meaning based upon the parts of the word and there are other activities that the teacher can do to improve students' morphological awareness. Second, the researcher suggests to the other researchers to have the writing task in different type of text, such as descriptive text, narrative text, and etc. where those materials are also studied in senior high school. So that students' writing accuracy can be explored more. Third, since this study finds that there is a correlation between students' morphological awareness and their accuracy in writing, the researcher suggests the other researchers to explore how to increase students' morphological awareness so the accuracy in writing task can be improved. It can be by giving the treatment to the students in the classroom. Fourth, because the researcher conducted the research in the senior high school level, the researcher suggests to the other researchers to try the same topic; about morphological awareness but in different level. It will be useful in developing the students' English skill from different levels.

\section{REFERENCES}

Asaad, H. Q. M., \&Shabdin, A. A. (2019).Conceptualization of morphological awareness and productive vocabulary knowledge with academic writing. International Journal of Academic Research in Business and Social Sciences, 8(1), 1-11.

Byrne, D. (1995). Teaching writing skills. New York: Longman.

Carlisle, J. F., \& Feldman, L. B. (1995).Morphological awareness and early reading achievement. Morphological aspects of language processing, 189209.

Farooq, M. S., Uzair-Ul-Hassan, M., \& Wahid, S. (2012).Opinion of second language learners about writing difficulties in English language.South Asian Studies (1026-678X), 27(1).

Hatch, E., \&Farhady, H. (1982).Research design and statistics for applied linguistics. Rowley: Newbury House.

McBRIDE-CHANG, C. A. T. H. E. R. I. N. E., Wagner, R. K., Muse, A., Chow, B. W. Y., \&Shu, H. U. A. (2005). The role of morphological awareness in children's vocabulary acquisition in English. Applied psycholinguistics, 26(3), 415-435.

Northey, M., McCutchen, D., \& Sanders, E. A. (2015). Contributions of morphological skill to children's essay writing. Reading and writing, 29(1), 47-68.

Nunan, D. (2003). Practical English language teaching. New York: McGraw Hill 
Silva, A. A., \& Martins-Reis, V. D. O. (2017). The influence of morphological awareness on reading and writing: a systematic review. In CoDAS (Vol. 29, No. 1, pp. e20160032e20160032).

Zakaria, C. (2018). The influence of students' morphological awareness toward students' writing ability at fourth semester students of English Language Education Department of Walisongo State Islamic University (UIN) of Semarang in the academic year of 2016/2017 (Doctoral dissertation, UIN Walisongo). 